\title{
Hormonal risk factors for breast cancer in Morocco: case-control study
}

\author{
Drissi Houda $^{1 *}$, Imad Fatima Ezzahra ${ }^{1}$, Bendahhou Karima ${ }^{2}$, Benider Abdelatif ${ }^{3}$, \\ Radallah Driss ${ }^{1}$
}

\author{
${ }^{1}$ Laboratory of Biology and Health, Associated Research Unit CNRST, URAC-34, Faculty of Sciences Ben M'sik \\ University Hassan II of Casablanca, Morocco \\ ${ }^{2}$ Cancer registry of the Greater Casablanca, Morocco \\ ${ }^{3}$ Center Mohammed VI for the Treatment of Cancers, Casablanca, Morocco
}

Received: 08 August 2019

Accepted: 07 September 2019

\author{
*Correspondence: \\ Dr. Drissi Houda, \\ E-mail: houda.drissi04@gmail.com
}

Copyright: () the author(s), publisher and licensee Medip Academy. This is an open-access article distributed under the terms of the Creative Commons Attribution Non-Commercial License, which permits unrestricted non-commercial use, distribution, and reproduction in any medium, provided the original work is properly cited.

\begin{abstract}
Background: The purpose of the study is to investigate hormonal risk factors and their impact on the development of this cancer.

Methods: This is a case-control study conducted at the Mohammed VI Centre for Cancer Treatment in Casablanca. Results: The average age of the patients is 50.43 years with a standard deviation of 11.21. Exposure to endogenous estrogens appears to have an impact on the occurrence of breast cancer in the population. The early age of menarche in patients is on average $13.31 \pm 1.69$ years compared to $13.65 \pm 1.54$ years in controls, with a significant difference $(\mathrm{p}=$ $0.01)$. Parity is on average 2.54 children in cases versus 2.94 in controls with a significant difference $(p=0.02)$. Regarding the distribution of the cumulative duration of breastfeeding, $19.3 \%$ of patients compared to $12.3 \%$ of controls breastfed their children for less than one year; $80.7 \%$ of cases compared to $87.7 \%$ of controls breastfed their children for more than one year $(\mathrm{OR}=0.58 ; 95 \% \mathrm{CI}$ : $0.35-0.97$; P trend=0.03). In addition, hypovitaminosis $\mathrm{D}$ was noted in $2.3 \%$ of patients compared to $0.3 \%$ of controls with $\mathrm{OR}=7.14 ; 95 \% \mathrm{CI}$ : $0.87-58.39$; $\mathrm{P}$ trend $=0.06$. In addition, the supply of exogenous estrogen would also be incriminated. The risk of breast cancer appears to be influenced mainly by oral contraceptive use, which was found in $60 \%$ of cases vs. $41.3 \%$ of controls with $\mathrm{OR}=2.07$; 95\% CI: 1.50 - 2.86; P trend=0.0001.

Conclusions: The results highlighted that breast cancer risk is highly dependent on early and prolonged exposure to estrogenic impregnation. This effect would be modulated by ovarian activity, puberty or menopause age, parity and breastfeeding.
\end{abstract}

Keywords: Breast cancer, Case-control study, Hormonal factors, Hypovitaminosis D, History of hormone therapy, Morocco

\section{INTRODUCTION}

Breast cancer is the leading women's cancer in the world and in Morocco. According to the RCGC, its incidence is gradually increasing from 35 per 100,000 in 2004 to 43.5 per 100,000 in $2012 .^{1,2}$ Although the etiology of this highly lethal disease remains uncertain, it has been established that one of the most powerful predictors of breast cancer risk in women is age, family history of the disease and genetic factors such as mutations in the BRCA1 and BRCA2 genes. Other well-established factors that increase breast cancer risk include hormonal 
and reproductive factors; lifestyle factors, linked to toxic habits, eating habits. The objective of the work is to investigate the hormonal and reproductive risk factors that may predispose women to breast cancer.

\section{METHODS}

This is a case-control study conducted at the Mohammed VI Centre for the treatment of cancers at the IBN ROCHD Hospital Centre in Casablanca. Participants are asked for prior informed consent to participate in the study. Popularized explanations are given to each of them about the research goals and the interest of the study.

The cases of breast cancer that were treated in the centre were included in the study from January 1, 2015 to December 31, 2016. The same number of controls free of any cancer disease was included among the patients admitted to the dermatology and ophthalmology consultations at the Ibn Rochd Casablanca University Hospital. Cases were matched to age controls, using age at diagnosis for cases and age at interview for controls. Data collection was done prospectively using a standardized questionnaire with several demographic data items including age at diagnosis, marital status, birth history, breastfeeding history, menopausal status, medical history and history of hormone therapy use.

Data entry was performed by Microsoft office Excel (2007) and variable analysis by Epi Info and R software. The study of the difference between cases and controls was evaluated by the chi-square test. The test is considered significant when $\mathrm{p}<0.05$. The association study between cases and controls for the different factors: Odds ratios (OR) and $95 \%$ confidence intervals (CI) were calculated using binary logistic regression analysis.

\section{RESULTS}

During the study period, a total of 305 newly diagnosed and managed breast cancer cases were included at the Mohammed VI Centre for Cancer Treatment, and 305 controls free of any cancer disease. Cases and controls are age-matched. The results regarding the age and medical history of the study population are presented in Table 1 .

Table 1: Age, marital status and medical history of cases and controls.

\begin{tabular}{|c|c|c|c|c|c|}
\hline & $\begin{array}{l}\text { Cases (\%) } \\
N=305\end{array}$ & $\begin{array}{l}\text { Controls }(\%) \\
N=305\end{array}$ & OR & IC à $95 \%$ & $P$ trend \\
\hline The average age & $50.43 \pm 11.21$ & & & & \\
\hline \multicolumn{5}{|l|}{ Marital status } & \multirow{5}{*}{0.09} \\
\hline Single & $52(17)$ & $41(13.4)$ & 1 & & \\
\hline Married & $170(55.7)$ & $198(64.9)$ & 0.67 & $0.42-1.07$ & \\
\hline Widow & $44(14.4)$ & $42(13.8)$ & 0.82 & $0.45-1.48$ & \\
\hline Divorced & $39(12.8)$ & $24(7.9)$ & 1.28 & $0.66-2.46$ & \\
\hline \multicolumn{5}{|l|}{ Diabetes } & \multirow{3}{*}{0.38} \\
\hline No & $271(88.9)$ & $264(86.6)$ & 1 & & \\
\hline Yes & $34(11.1)$ & $41(13.4)$ & 0.80 & $0.49-1.31$ & \\
\hline \multicolumn{5}{|c|}{ Hormonal disorders } & \multirow{3}{*}{0.13} \\
\hline No & $294(96.4)$ & $300(98.4)$ & 1 & & \\
\hline Yes & $11(3.6)$ & $5(1.6)$ & 2.24 & $0.77-6.54$ & \\
\hline \multicolumn{5}{|c|}{ Hypovitaminosis D } & \multirow{3}{*}{0.06} \\
\hline No & $298(97.7)$ & $304(99.7)$ & 1 & & \\
\hline Yes & $7(2.3)$ & $1(0.3)$ & 7.14 & $0.87-58.39$ & \\
\hline
\end{tabular}

The average age of all patients is 50.43 years, with a standard deviation of 11.21 years with extremes ranging from 23 to 95 years. Regarding marital status $55.7 \%$ of our patients were married versus $64.9 \%$ of controls, $17 \%$ of cases were single versus $13.4 \%$ of controls and $14.4 \%$ of cases were widowed versus $13.8 \%$ of controls with $(\mathrm{OR}=0.64 ; 95 \% \mathrm{CI}: 0.42-1.07 ; \mathrm{P}$ trend $=0.09)$. Among the women interviewed, $11.1 \%$ of cases are diabetic vs. $13.4 \%$ of controls and $3.6 \%$ of patients were followed for a hormonal disorder vs. $1.6 \%$ of controls.

Concerning hypovitaminosis $\mathrm{D}$, it is present in $2.3 \%$ of patients compared to $0.3 \%$ of controls, no association has been found between diabetes, hormonal disorder, hypovitaminosis $\mathrm{D}$ and breast cancer risk, with respectively $(\mathrm{OR}=0.8 ; 95 \% \mathrm{CI}: 0.49-1.31 ; \mathrm{P}$ trend $=$ 0.38); $(\mathrm{OR}=2.24 ; 95 \% \mathrm{CI}: 0.77-6.54 ; \mathrm{P}$ trend $=0.13)$; $(\mathrm{OR}=7.14 ; 95 \% \mathrm{CI}: 0.87-58.39 ; \mathrm{P}$ trend $=0.06)$.

\section{Gyneco-obstetrical history:}

The data collected, particularly on gynaeco-obstetrical history, are shown in Table 2 . In the study population, the average age of first pregnancy is 23.66 years for cases versus 24.35 years for controls, with an insignificant $\mathrm{p}(\mathrm{p}$ $=0.2$ ). Parity is on average 2.54 children in cases vs. 2.94 
in controls with a significant difference $(p=0.02) .26 .9 \%$ of women with cancer are nulliparous compared to $20 \%$ of controls. Thus, parity seems to be a protective factor against the occurrence of breast cancer with $\mathrm{OR}=0.68$; 95\% CI: $0.46-0.99 ; \mathrm{P}$ trend $=0.04$. At the same time, $25.6 \%$ of the breast cancer cases had 1 to 2 children compared to $24.6 \%$ of controls and $47.5 \%$ of cases had more than two children compared to $55.4 \%$ of controls. Indeed, multiparity seems to be a protective factor against the occurrence of breast cancer with $\mathrm{OR}=0.63 ; 95 \% \mathrm{CI}$ : $0.42-0.95 ; \mathrm{P}$ trend $=0.02$. In the results, among multiparous women, $96.4 \%$ of cases breastfed their children vs. $92.6 \%$ of controls with OR $=0.46 ; 95 \% \mathrm{CI}$ : 0.19 - 1.09; $\mathrm{P}$ trend $=0.08$.

Table 2: Gyneco-obstetrical history of patients and controls.

\begin{tabular}{|c|c|c|c|c|c|}
\hline & $\begin{array}{l}\text { Cases (\%) } \\
\mathrm{N}=305\end{array}$ & $\begin{array}{l}\text { Controls (\%) } \\
\text { N=305 }\end{array}$ & OR & IC à 95\% & p trend \\
\hline Average number of pregnancies & $3.13 \pm 2.62$ & $3.65 \pm 2.75$ & & & 0.01 \\
\hline \multicolumn{5}{|l|}{ Pregnancy distribution } & \multirow{4}{*}{0.13} \\
\hline No pregnancies & $71(23.3)$ & $59(19.3)$ & 1 & & \\
\hline 1 to 2 pregnancies & $65(21.3)$ & $55(18)$ & 0.98 & $0.59-1.61$ & \\
\hline More than 2 pregnancies & $169(55.4)$ & $191(62.6)$ & 0.73 & $0.49-1.10$ & \\
\hline Average age of 1st pregnancy & $23.66 \pm 5.97$ & $24.35 \pm 5.87$ & & & 0.2 \\
\hline Average number of children & $2.54 \pm 2.20$ & $2.94 \pm 2.24$ & & & 0.02 \\
\hline \multicolumn{5}{|l|}{ Parity frequency } & \multirow{3}{*}{0.04} \\
\hline No & $82(26.9)$ & $61(20)$ & 1 & & \\
\hline Yes & $223(73.1)$ & $244(80)$ & 0.68 & $0.46-0.99$ & \\
\hline \multicolumn{5}{|l|}{ Distribution of parity } & \multirow{4}{*}{0.02} \\
\hline No children & $82(26.9)$ & $61(20)$ & 1 & & \\
\hline 1 to 2 children & $78(25.6)$ & $75(24.6)$ & 0.77 & $0.48-1.22$ & \\
\hline More than 2 children & $145(47.5)$ & $169(55.4)$ & 0.63 & $0.42-0.95$ & \\
\hline \multicolumn{5}{|l|}{ Frequency of breastfeeding } & \multirow{3}{*}{0.08} \\
\hline No & $8(3.6)$ & $18(7.4)$ & 1 & & \\
\hline Yes & $215(96.4)$ & $226(92.6)$ & 0.46 & $0.19-1.09$ & \\
\hline \multicolumn{5}{|l|}{ Distribution of breastfeeding time } & \multirow{3}{*}{0.03} \\
\hline Less than one year of breastfeeding & $43(19.3)$ & $30(12.3)$ & 1 & & \\
\hline More than one year of breastfeeding & $180(80.7)$ & $214(87.7)$ & 0.58 & $0.35-0.97$ & \\
\hline
\end{tabular}

Regarding the distribution of the cumulative duration of breastfeeding, we noted that $19.3 \%$ of patients had breastfed their children for less than one year compared to $12.3 \%$ of controls; $80.7 \%$ of cases vs. $87.7 \%$ of controls breastfed their children for more than one year. Indeed, the cumulative duration of breastfeeding of more than one year seems to be a protective factor against the occurrence of breast cancer with $\mathrm{OR}=0.58 ; 95 \% \mathrm{CI}$ : $0.35-0.97 ; \mathrm{p}$ trend $=0.03$.

\section{History of hormone therapy use}

Data on hormone treatment use and menopausal status in patients and controls are shown in Table 3. The age of the menarche is on average 13.31 1.69 years for patients compared to $13.65 \pm 1.54$ years for controls, with a significant difference $(\mathrm{p}=0.01)$. The mean age of onset of menopause was $49.86 \pm 5.11$ years for cases vs. $49.34 \pm 3.63$ years for controls, with an insignificant $p$ $(p=0.2)$. More than half of our patients are menopausal with a proportion of $56.1 \%$, followed by patients with pre-menopausal status with a proportion of $37.4 \%$ and finally patients with peri-menopausal status with a proportion of $6.6 \%$. The distribution of controls by menopausal status follows the same trend as the cases, with respectively $55.4 \% ; 39 \% ; 5.6 \%$ and $\mathrm{OR}=1.22 ; 95 \%$ CI: $0.62-2.46 ; \mathrm{P}$ trend $=0.56$. In addition, oral contraceptive use was found in $60 \%$ of cases vs. $41.3 \%$ of controls, with OR $=2.07 ; 95 \% \mathrm{CI}: 1.50-2.86 ; \mathrm{P}$ trend $=$ 0.0001 . $62.3 \%$ of patients had used oral contraceptives for more than 5 years vs. $54 \%$ of controls with $\mathrm{OR}=$ 1.40; $95 \%$ CI: $0.88-2.23$; $\mathrm{p}$ trend $=0.14$.

As for other medical history data for the study population, follow-up of hormone replacement therapy (HRT) or breast mastosis treatment was low in patients, with $3.3 \%$ of cases vs. $2 \%$ of controls with $\mathrm{OR}=1.68$; 95\% CI: $0.60-4.70$; $\mathrm{P}$ trend $=0.3$ and $3.6 \%$ of cases vs. $1.6 \%$ of controls with OR $=2.24 ; 95 \%$ CI: $0.77-6.54 ; \mathrm{P}$ trend $=0.1$. Similarly, $8.5 \%$ of cases were followed for cycle irregularity treatment compared to $4.6 \%$ of controls with $\mathrm{OR}=1.93 ; 95 \% \mathrm{CI}: 0.99-3.78 ; \mathrm{P}$ trend $=0.05$. Thus, no association has been found between hormone treatments outside oral contraceptives and breast cancer risk. In contrast, $10.8 \%$ of patients were treated with ovulation inducers compared to $4.9 \%$ of controls with OR $=2.34 ; 95 \%$ CI: $1.24-4.41 ; \mathrm{P}$ trend $=0.008$ 
Table 3: History of hormone therapy use and menopausal status in patients and controls.

\begin{tabular}{|c|c|c|c|c|c|}
\hline & $\begin{array}{l}\text { Cases (\%) } \\
\mathrm{N}=\mathbf{3 0 5}\end{array}$ & $\begin{array}{l}\text { Controls (\%) } \\
\mathrm{N}=305\end{array}$ & OR & IC à 95\% & p trend \\
\hline \multicolumn{5}{|l|}{ Menopausal status } & \multirow{4}{*}{0.8} \\
\hline Pre-menopausal & $114(37.4)$ & $119(39)$ & 1 & & \\
\hline Perimenopausal & $20(6.6)$ & $17(5.6)$ & 1.22 & $0.61-2.46$ & \\
\hline Post-menopausal & $171(56.1)$ & $169(55.4)$ & 1.05 & $0.75-1.47$ & \\
\hline The average age at menarche & $13.31 \pm 1.69$ & $13.65 \pm 1.54$ & & & 0.01 \\
\hline The average age at menopause & $49.86 \pm 5.11$ & $49.34 \pm 3.63$ & & & 0.2 \\
\hline \multicolumn{5}{|l|}{ Hormone replacement therapy } & \multirow{3}{*}{0.3} \\
\hline No & $295(96.7)$ & $299(98)$ & 1 & & \\
\hline Yes & $10(3.3)$ & $6(2)$ & 1.68 & $0.60-4.70$ & \\
\hline \multicolumn{5}{|l|}{ Ovulation inducers } & \multirow{3}{*}{0.008} \\
\hline No & $272(89.2)$ & $290(95.1)$ & 1 & & \\
\hline Yes & $33(10.8)$ & $15(4.9)$ & 2.34 & $1.24-4.41$ & \\
\hline \multicolumn{5}{|l|}{ Treatment of cycle irregularity } & \multirow{3}{*}{0.05} \\
\hline No & $279(91.5)$ & $291(95.4)$ & 1 & & \\
\hline Yes & $26(8.5)$ & $14(4.6)$ & 1.93 & $0.99-3.78$ & \\
\hline \multicolumn{5}{|l|}{ Treatment of breast mastosis } & \multirow{3}{*}{0.1} \\
\hline No & $294(96.4)$ & $300(98.4)$ & 1 & & \\
\hline Yes & $11(3.6)$ & $5(1.6)$ & 2.24 & $0.77-6.54$ & \\
\hline \multicolumn{5}{|l|}{ Oral Contraception (OC) } & \multirow{3}{*}{0.0001} \\
\hline No & $122(40)$ & $179(58.7)$ & 1 & & \\
\hline Yes & $183(60)$ & $126(41.3)$ & 2.07 & $1.50-2.86$ & \\
\hline \multicolumn{5}{|c|}{ Distribution of the duration of $\mathrm{CO}$} & \multirow{3}{*}{0.09} \\
\hline Less than 5 years old & $69(37.7)$ & $58(46)$ & 1 & & \\
\hline More than 5 years & $114(62.3)$ & $68(54)$ & 1.40 & $0.88-2.23$ & \\
\hline
\end{tabular}

\section{DISCUSSION}

This study carried out at the Mohammed VI centre for cancer treatment, Ibn Rochd University Hospital of Casablanca, made it possible to define the hormonal and reproductive risk factors for breast cancer in a Moroccan population.

Age is one of the most important risk factors for this cancer. In the study the results show that the average age of the patients is 50.43 years. Several studies report that breast cancer is rare in women under 30 years of age and the risk increases between 50 and 75 years of age (almost two-thirds of breast cancers). ${ }^{3}$ Exposure to estrogens is one of the most important risk factors for the development and recurrence of hormone-dependent breast cancer. ${ }^{4}$

The age of puberty determines when the ovaries become functional and begin to produce estrogen. Early puberty exposes women to female hormones for a longer period of time, thus increasing the risk of breast cancer. ${ }^{5}$ This data is found in the study, since the age of the menarche is on average $13.31 \pm 1.69$ years in patients compared to $13.65 \pm 1.54$ in controls with a significant difference $(\mathrm{p}=$ 0.01 ). On the other hand, a late menopause exposes you to estrogen for a longer period of time. This data does not appear to have an impact on our population, since the average age of onset of menopause in our patients is comparable to that of controls, $49.86 \pm 5.11$ years versus $49.34 \pm 3.63$ years, respectively.

Several studies have also shown that parity and breastfeeding reduce the risk of breast cancer. From our results, parity seems to be a protective factor with $\mathrm{OR}=$ 0.68. The protective effect of multiparity seems to increase with the number of births. According to Russo et al, women who have had eight to nine births have a reduced risk of about $30 \%$ compared to those who have had five births. ${ }^{6}$

Other epidemiological data indicate that the risk of breast cancer increases with nulliparity. ${ }^{7}$ nulliparous women have a relative risk (RR) twice as high as those who had their first pregnancy before 20 years of age. ${ }^{7}$ This risk increases gradually with age at first pregnancy, it is 2.4 if pregnancy occurs after 35 years of age. Women who have had a late pregnancy (after 35 years) have an increased risk of breast cancer for 15 years after pregnancy. ${ }^{8}$ After the first full-term pregnancy, the age of other pregnancies has little influence..$^{9,10}$

At the same time, we noted that the cumulative duration of breastfeeding would have an impact on the occurrence 
of breast cancer. The results are supported by a metaanalysis of 47 case-control or cohort epidemiological studies in 30 countries examining the relationship between breastfeeding and breast cancer. ${ }^{11}$ Similarly, a prospective study confirms that breastfeeding mothers have a reduced risk of developing the disease by about $30 \%$ and a significant reduction in risk has been reported for a 6 -month breastfeeding period. ${ }^{12}$ In addition, if breast cancer develops, the prognosis is better and recurrence is less when the mother has breastfed. ${ }^{13}$

Pregnancy and breastfeeding provide protection by causing differentiation of breast tissue, which ultimately reduces the risk of carcinogenesis. The protective role of long-term pregnancy is thought to be related not only to post-pregnancy breast involution and architectural changes in the breast, but also to genomic changes. ${ }^{8}$ Breast cell differentiation is further enhanced by breastfeeding. In order to produce milk efficiently, the cells of the mammary epithelium complete their maturation. Thus, the lobules are optimized and are less sensitive to estrogen and carcinogens. ${ }^{12}$ Another mechanism mentioned concerns the fact that milk production allows exfoliation of breast tissue, which helps to eliminate cells potentially carrying DNA damage. ${ }^{12}$ Breastfeeding time is also a period of lower estrogen exposure when the amenorrhea period is longer, thus reducing cumulative estrogen exposure in women. ${ }^{13}$

Exogenous hormonal factors such as the use of oral contraceptives or menopause hormone treatments also contribute to changing the risk of breast cancer. Oral contraceptive use was found in $60 \%$ of cases versus $41.3 \%$ of controls with $\mathrm{OR}=2.07 ; 95 \% \mathrm{CI}$ : $1.50-2.86 ; \mathrm{P}$ trend $=0.0001$. In addition, $62.3 \%$ of patients had used oral contraceptives for more than 5 years versus $54 \%$ of controls with $\mathrm{OR}=1.40 ; 95 \% \mathrm{CI}: 0.88-2.23 ; \mathrm{P}$ trend $=0.14$.Thus, the use of estrogen-progestin oral contraceptives would be responsible for an increased risk of breast cancer in the women in our study, which is consistent with a case-control study suggesting that oral contraceptive use, especially at an early age (before first pregnancy), is associated with an increased risk of breast cancer before menopause. ${ }^{14}$ Similarly, a meta-analysis of 54 epidemiological studies showed that the risk of developing breast cancer increases by $24 \%$ among women using oral contraceptives. ${ }^{15}$ However, no significant increase in risk occurs once their use is stopped. ${ }^{15}$

In addition, hormone replacement therapy prolongs natural estrogen impregnation and places the treated woman at a higher risk level than a woman of the same age without treatment. ${ }^{16}$ No association was found in our study between these hormone treatments and breast cancer risk. However, it has been shown that among women who use HRT, the risk of breast cancer increases with duration of use and decreases after stopping treatment. ${ }^{17}$ The mechanisms cited to explain the increased risk of breast cancer are increased proliferation of mammary epithelial cells, the effect of promoting the development of pre-existing lesions and increased breast density. ${ }^{18,19}$

Several studies also point out that vitamin D deficiency is often associated with the development of breast cancer. The same is true in the study population where hypovitaminosis D was present in $2.3 \%$ of patients compared to $0.3 \%$ of controls with $(\mathrm{OR}=7.14 ; 95 \% \mathrm{CI}$ : $0.87-58.39 ; \mathrm{P}$ trend $=0.06)$. According to a large cohort study of white women, dietary intake of vitamin D combined with exposure to sunlight would reduce the risk of breast cancer by 15 to $36 \% .^{20}$ It has also been suggested an inverse relationship between high vitamin D intake ( $>500 \mathrm{IU} /$ day or $12.5 \mu \mathrm{g} / \mathrm{day}$ ) and a $28 \%$ reduction in breast cancer risk in premenopausal women. ${ }^{20}$ In addition, the meta-analysis by Mohr et al. published in 2014 showed that breast cancer patients with high levels of vitamin $\mathrm{D}$ have twice the cure rates. ${ }^{21}$ The protective mechanism of vitamin D is not fully understood. However, it appears that calcitriol, the active form of vitamin $\mathrm{D}$, reduces the activity of aromatase, an enzyme that promotes estrogen synthesis. ${ }^{22}$ For example, vitamin D may limit exposure to estrogen.

\section{CONCLUSION}

Thus, the exploration of the hormonal factors of the study participants raised the existence of several elements, known as risk factors for breast cancer such as early onset of menstruation, absence of children or late pregnancies, short-term breastfeeding, use of oral contraceptives and in the case of hypovitaminosis D.

Some of these results nevertheless need to be completed. More targeted studies of larger female populations can be conducted to explore the association between each of these hormonal factors and the occurrence of breast cancer in Moroccan women.

\section{Funding: No funding sources}

Conflict of interest: None declared

Ethical approval: The study was approved by the Institutional Ethics Committee

\section{REFERENCES}

1. Tazi MA, Benjaafar N, Raki A. Cancer incidence in Rabat, Morocco: 2006-2008. Ecancermedicalscience. 2013;7:338.

2. Benider A, Othmani BM, Harif M, Karkouri M, Quessar A, Sahraoui S, et al. Registre des cancers de la région du Grand Casablanca, Année. 2004;2007.

3. Nkondjock A, Ghadirian P. Risk factors for breast cancer. Medical Sciences. 2005;21(2):175-80.

4. Odermatt, R. Wolfer, A. Zaman, K. Hormone therapy in breast cancer: efficacy and adverse effects. Rev Med Switzerland. 2013;9:1090-4.

5. Chapelon C, Touillaud F, Fournier MA. What risks, for which women? Breast cancer risk factors; 30th SFSPM days, La Baule. 2008. 
6. Russo J, Hu Yf, Yang X, Russo IH. Developmental, cellular, and molecular basis of human breast cancer. J Natl Cancer InstMonogr. 2000;8:17-37.

7. Mathelin C, Guldenfels C, Croce S. Epithelial breast lesions with atypia: diagnostic, therapeutic and monitoring management. Therapeutic Medicine. 2009; 15(4):312-21.

8. Lesieur B, Vercambre M, Dubernard G, Khosrotehrani K, Uzan S, Aractingi S, Rouzier R. Risk of pregnancy-related breast cancer. J Obstet Gynecol Repro Biol. 2008;37(1):77-81.

9. Kelsey JL. A review of the epidemiology of human breast cancer. Epidemiol Rev. 1979;1:74-109.

10. Ramon JM, Escriba JM, Casas I, Benet J, Iglesias C, Gavalda L, et al. Age at first full-term pregnancy, lactation and parity and risk of breast cancer: a casecontrol study in Spain. Eur $\mathbf{J}$ Epidemiol. 1996;12(5):449-53.

11. Freund C, Mirabel L, Annane K, Mathelin C. Breastfeeding and breast cancer. Gynecol Obst Fertility. 2005;33(10):739-44.

12. Kwan, Marilyn L, Bernard, Philip S, Kroenke, Candyce H. Breastfeeding, PAM50 tumor subtype, and breast cancer prognosis and survival. J National Cancer Institute. 2015;107:7-087.

13. Helewa M, Levesque P, Provencher D. Breast cancer, pregnancy and lactation. J Obstet Gynaecol Can. 2002;24(2):164-71.

14. Engel P, Fagherazzi G, Boutten A, Dupré T, Mesrine S, Ruault MC, Chapelon CF. Serum $25(\mathrm{OH})$ vitamin $\mathrm{D}$ and risk of breast cancer: a nested case-control study from the French E3N cohort. Cancer Epidemiol Biomarkers Prev. 2010;19(9):2341-50.

15. Morère JF, Penault LF, Aapro MS, Salmon R. Le cancer du sein. Springer Sci Business Media. 2008;316:25-6.
16. Agence française de sécurité sanitaire des produits de santé. Traitement hormonal substitutif de la ménopause, 2005. Available at https://www.ansm.sante.fr/var/ansm_site/storage/orig inal/application/9f6f8e565b5c23b497549ef4c50b2fe 2.pdf. Accessed on 9 June 2019.

17. Reeves GK, Beral V, Green VT, Gathani D. Million women study collaborators hormonal therapy for menopause and breast-cancer risk by histological type: a cohort study and meta-analysis. Lancet Oncol. 2006;7(11):910-8.

18. Chlebowski RT, Hendrix SL, Langer RD. Influence of estrogen plus progestin on breast cancer and mammography in healthy postmenopausal women: the women's health initiative randomized trial. JAMA. 2003;289(24):3243-53.

19. Cogliano V, Grosse Y, Baan R. Carcinogenicity of combined oestrogen-progestagen contraceptives and menopausal treatment. Lancet Oncol. 2005;6(8):552-3.

20. Mosekilde L. Vitamin D and the elderly. Clin Endocrinol. 2005;62:265-81.

21. Mohr SB. Meta-analysis of Vitamin D sufficiency for improving survival of patients with breast cancer. Anticancer Research. 2014;34:1163-6.

22. Krishnan AV, Swami S, Peng L, Wang J, Moreno J, Feldman D. Tissue-selective regulation of aromatase expression by calcitriol: implications for breast cancer therapy. Endocrin. 2010 ;151(1):32-42.

Cite this article as: Drissi $\mathrm{H}$, Imad FZ, Bendahhou $\mathrm{K}$, Benider A, Radallah D. Hormonal risk factors for breast cancer in Morocco: case-control study. Int J Reprod Contracept Obstet Gynecol 2019;8:4008-13. 